\title{
RADIOCARBON, SOIL, AND ARTIFACT CHRONOLOGIES FOR AN EARLY SOUTHERN OREGON COASTAL SITE
}

\author{
Roberta Hall ${ }^{1,2} \bullet$ Loren G Davis $^{1} \bullet$ Samuel Willis ${ }^{1} \cdot$ Matthew Fillmore $^{3}$ \\ ABSTRACT. Radiocarbon dates together with geoarchaeological, soil, and lithic analyses are presented to describe archae- \\ ological site 35-CS-9 in Bandon Ocean Wayside State Park, Oregon, northwestern USA. One of the few Oregon middle- \\ Holocene coastal sites that includes sediments and artifacts dating to the early Holocene and possibly to the late Pleistocene, \\ it was recorded in 1951 and surface surveyed by archaeologists in 1975, 1986, and 1991, but its depth and antiquity were not \\ tested. In February 2002, we studied the site's stratigraphy and sediments and described 8 strata from the aeolian surface to \\ bedrock at $350 \mathrm{~cm}$ depth. Soil samples taken from a cut bank for texture classification, particle size analysis, $\mathrm{pH}$, carbon \\ content, and chemical analysis suggested that the site represented a complete history of Holocene deposits. Excavation of 2 \\ test units in August 2002 uncovered substantial lithic and charcoal remains that confirm a protracted middle-Holocene \\ occupation and suggest that human occupation began in the early Holocene. Charcoal recovered at $235-245 \mathrm{~cm}$ dated to \\ $11,000{ }^{14} \mathrm{C} \mathrm{BP}$, and the deepest lithic artifact was recovered in a level at $215-225 \mathrm{~cm}$. Whether the human occupation was con- \\ tinuous throughout the Holocene, and whether it began in the early Holocene or in the late Pleistocene, can only be determined \\ with further excavations.
}

\section{INTRODUCTION}

Until recently, many archaeologists posited that settlement of the Pacific coast was achieved by people from the interior who moved west along river valleys to the coast and gradually became fully marine adapted (Ross 1984; Lyman and Ross 1988). In the last decade, however, archaeological and paleoecological studies from Alaska to southern California have shown that by 16,000 yr ago, some northwest Pacific coastal habitat was ice-free and that the earliest archaeologically known people ate marine resources (Dixon 2001; Erlandson 2002; Fedje et al. 2001; Madsen 2004). Although the possibility that the Americas were settled by people moving along the northeastern Pacific coastline during the early warming years following the last glacial maximum has been considered for several decades, only in the last $15 \mathrm{yr}$ has it been investigated seriously (Dixon 2001; Hall et al. 2004; Madsen 2004; Mandryk et al. 2001). The coastal-settlement hypothesis is difficult to test because the postglacial rise of worldwide sea levels has drowned much of the continental shelf that made up the coastline during the Pleistocene-Holocene transition. In a few exceptional places, geological processes have facilitated preservation. For example, several sites in the Queen Charlotte Islands and a site in the Channel Islands off southern California have archaeological deposits from this period (Fedje et al. 2001; Erlandson et al. 1996). In the Charlottes, changes in sea level produced by deglaciation and glacial-isostatic rebound first submerged and then exposed archaeological sediments. On California's Channel Islands, unique conditions of preservation in caves, together with the absence of mammals that would be likely to disturb cultural remains, have favored the preservation of archaeological deposits that include fiber artifacts. Oregon's coast lacks large offshore islands, has no history of glaciation or of fjords formed by glaciers, and has no extensive areas protected from the Pacific's vigorous storms. Coastal bluffs representing deposits of Pleistocene age have been seriously deflated, and many river valleys have been inundated or filled with very thick alluvial deposits.

One explanation for the inland bias toward North American settlement in general, and Oregon settlement in particular, is the paucity of coastal sites that are older than $3000 \mathrm{yr}$, an absence that could

\footnotetext{
${ }^{1}$ Department of Anthropology, Oregon State University, Corvallis, Oregon 97331, USA.

${ }^{2}$ Corresponding author. Email: rhall@oregonstate.edu.

${ }^{3}$ United States Department of Agriculture, USDA-NRCS, Tangent Soils Office, 33630 McFarland Road, Tangent, Oregon 97389, USA.
} 
be due to geological forces and historic events. Rising sea levels in the early Holocene flooded the former coast and any possible evidence of a human presence. Since the coastal margin became established about $6000 \mathrm{yr}$ ago, it has been impacted by relentless wind, rain, earthquakes, and other geological forces that have produced both subsidence and uplift. Deflation of surface sediments that may expose lithic artifacts make dating them very difficult, and the opposite effect, deep burial, is produced in some places by shifting dunes or alluvial deposits. Furthermore, the near-coastal environment is obscured in many places by dense vegetation. Another obstacle that archaeologists face in seeking early sites along the Oregon coast is commercial and residential development that has destroyed, disturbed, or covered many sites. Additionally, the numerous archaeological sites that date to the last several millennia are recognized by characteristics of recent rather than of ancient cultures, such as extensive shell middens that alter the acidity of the soil and help to preserve bone (Ross 1984; Hall 1995). Because the present-day coast is a few kilometers inland of the late-Pleistocene coast, any remnants of a human occupation are likely to lack both mollusk and bone remains. Sites lacking these elements may not be recognized, particularly if the earliest settlements were not long term.

Archaeological investigations often begin with the discovery of artifacts or other evidence of a past human occupation and then proceed to onsite studies that ultimately answer such central questions as when the site was occupied, what occurred at the site, and what it tells about human prehistory. The project we devised (Hall 2000) instead works from the premise that in order to find sites dating to the late Pleistocene or to the early Holocene along the Oregon coast, it is necessary to first locate landscapes where sediments of the appropriate age exist. Thus, we first mined past archaeological and geological experience and literature and then did field surveys. Our strategy was to locate areas with sediments between 8000 and 15,000 yr old that would have connected with the now-submerged former coast and that offered resources such as fresh water, tool-making materials, and food. After finding such places, we tested them for archaeological material. Despite the obvious logic of this approach, this methodology is not common (Hall et al. 2002); one exception is found in studies of the Queen Charlotte Islands and coastal southwestern Alaska (Fedje et al. 2004; Fedje and Christensen 1999; Ramsey et al. 2004).

In this paper, we report radiocarbon tests, artifacts, and soil characteristics at archaeological site 35CS-9 in Bandon Ocean Wayside State Park, Coos County, just south of the city of Bandon, Oregon (Figure 1). This Oregon coastal site represents a significant middle-Holocene occupation that probably began in the early Holocene, or possibly in the late Pleistocene. Therefore, it is among the earliest archaeological sites known on Oregon's Pacific coast. Others include Tahkenitch Lake, 35-DO130 (earliest date: $7960 \pm 90{ }^{14} \mathrm{C}$ BP; Minor and Toepel 1986); Blacklock Point, 35-CU-75 (earliest date: $7650 \pm 80{ }^{14} \mathrm{C}$ BP; Minor 1994); and Indian Sands, 35-CU-67C (earliest date: $10,430 \pm 150{ }^{14} \mathrm{C}$ BP; Davis et al. 2004).

${ }^{14} \mathrm{C}$ tests are especially crucial when sites seem to breach or extend accepted borders or frontiers, or when sites differ in significant ways from those that are well known. At the earliest coastal sites, archaeological visibility is a significant problem that requires considerably more geomorphological work and paleoecological modeling than is needed in studying sites with mollusk and organic material. Materials that are likely to be present 10,000 or more years after deposition are stone tools and possibly fire-cracked rock and charcoal from hearths. Antiquity of the site must be established by dating charcoal in levels where stone tools also have been excavated. 


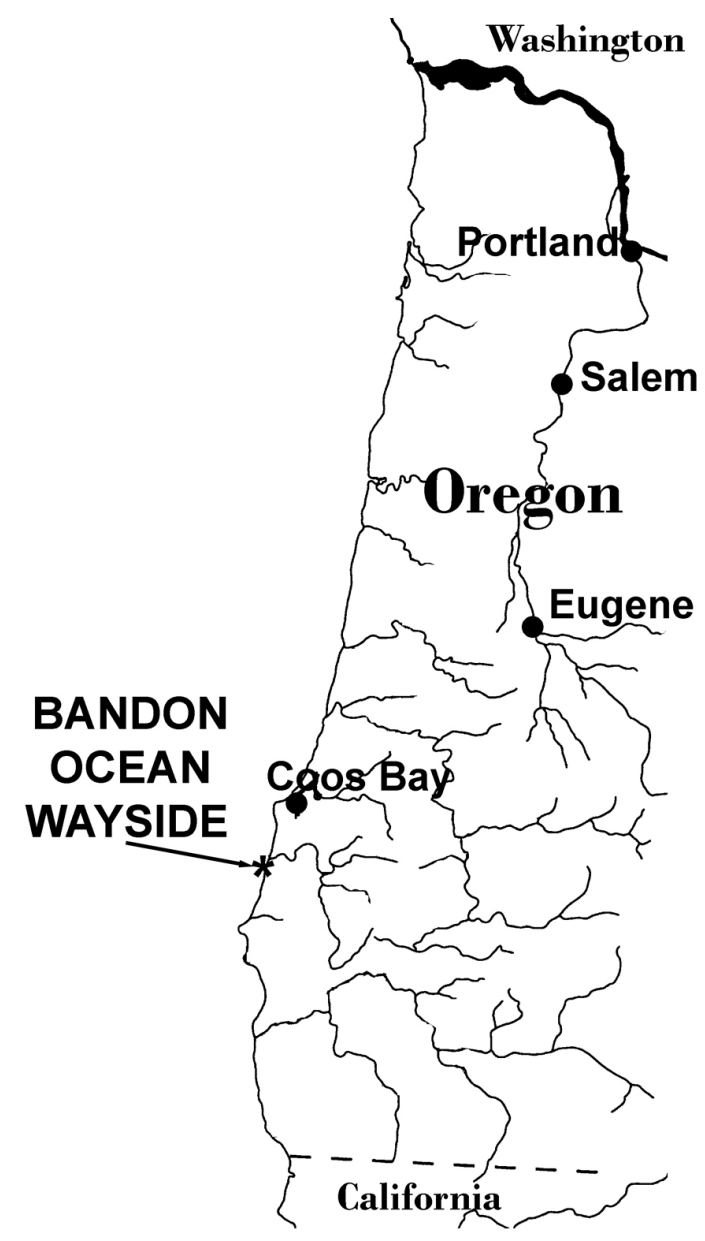

Figure 1 Site location

\section{CS-9, ARCHAEOLOGICAL HISTORY}

Four teams of archaeologists examined the surface of 35-CS-9 before our team performed test excavations in 2002. Characterized as an open bluff site, 35-CS-9 was first identified by Lloyd Collins during a regional archaeological survey in 1951. In the early 1970s, archaeologist Richard Ross performed a survey-evaluation on behalf of Oregon State Parks and, like Collins, he noted chert flakes eroding out of a black pebbly matrix just beneath the sod. Ross (1975:2) wrote that "Collins recorded the idea that 'the shell had been stripped from the site leaving a hard black pebbly matrix with flakes of chert in situ.' I think this is erroneous and it is quite possible that the site was not originally a shell midden but rather is one of the 'bluff' sites... as such it could be an important older site and something different from the typical shell midden." In his evaluation of archaeological sites on state lands along the coast, Minor (1986:78) wrote about 35-CS-9: "This site has long-term research potential." Erlandson and Moss (1993) expressed concern about the site's stability due to erosion. Like Ross and Minor before them, Erlandson and Moss recommended that test excavations be made to characterize its constituents. In 2001, Erlandson suggested to the lead author that we consider including the site in our exploratory program (Hall 2000). 
In February 2002, authors Davis and Fillmore included Bandon Ocean Wayside with 4 other coastal locations (Samuel H Boardman State Park, Neptune State Park, Otter Point State Park, and Cape Blanco State Park) to evaluate natural formation processes that could help us locate sediments dating to the Pleistocene-Holocene transition. Based in large part on these evaluations, we applied for excavation permits at Samuel H Boardman State Park and Bandon Ocean Wayside and conducted test excavations in August 2002. Findings at 35-CU-67C within Boardman State Park, including a $10,430 \pm 150{ }^{14} \mathrm{C} \mathrm{BP}$ date from a charcoal sample in a level at $70 \mathrm{~cm}$ depth that also held stone artifacts, have been reported (Davis et al. 2004). At 35-CS-9, excavations involved two $1 \times 2-\mathrm{m}$ test units placed within $2 \mathrm{~m}$ of each other and only $3 \mathrm{~m}$ from the cut bank from which soil samples were taken the previous February and where strata had been described. Both units A and B proved to hold archaeological data. Excavation followed traditional archaeological procedures, including the use of arbitrary 10-cm levels. Units A and B provided 23 stone artifacts, 1239 pieces of debitage, and charcoal samples in every level from 6 through 21 . The ubiquity of charcoal and the presence of considerable fire-cracked rock suggest that at least some of the charcoal was culturally deposited. A feature in Unit A at $175 \mathrm{~cm}$ depth, associated with charcoal, appears likely to have been part of a hearth.

\section{METHODS OF ANALYSIS}

\section{${ }^{14} \mathrm{C}$ Analysis}

We submitted 5 charcoal samples from 35-CS-9 to Beta Analytic, Inc. (USA), 2 in 2002, and 3 in 2003. We chose samples that appeared of adequate size and that represented both units and the range of depths available. Treatment and analysis type were determined in consultation with Beta Analytic and included standard ${ }^{14} \mathrm{C}$ analysis, with and without extended counting, and accelerator mass spectrometry (AMS) (Table 1).

Table $1{ }^{14} \mathrm{C}$ samples at Bandon Ocean Wayside (35-CS-9), Oregon.

\begin{tabular}{lllcc}
\hline Lab number & Provenience & $\begin{array}{l}\text { Testing method and } \\
\text { material }\end{array}$ & ${ }^{14}$ C date BP & $\begin{array}{c}\text { Calibrated } \\
\text { date BPa }(1 \sigma)\end{array}$ \\
\hline Beta-189635 & $\begin{array}{l}\text { Unit B, level 6, } \\
89-91 \mathrm{~cm} \text { B.S. }\end{array}$ & AMS, charcoal & $2600 \pm 40$ & $2760-2740$ \\
Beta-170404 & $\begin{array}{l}\text { Unit B, level 8, } \\
\text { 103-113 cm B.S. }\end{array}$ & Radiometric, charcoal & $2970 \pm 70$ & $3250-3000$ \\
Beta-170405 & $\begin{array}{l}\text { Unit B, west wall, } \\
\text { 150 cm B.S. }\end{array}$ & AMS, charcoal & $5820 \pm 40$ & $6590-6570$ \\
Beta-189637 & $\begin{array}{l}\text { Unit A, level 13, } \\
\text { 155-165 cm B.S. }\end{array}$ & $\begin{array}{l}\text { Radiometric, charcoal; } \\
\text { extended counting }\end{array}$ & $5900 \pm 80$ & $6780-6650$ \\
Beta-189636 & $\begin{array}{l}\text { Unit A, level 21, } \\
\text { 235-245 cm B.S. }\end{array}$ & $\begin{array}{l}\text { Radiometric, charcoal; } \\
\text { extended counting }\end{array}$ & $11,000 \pm 140$ & $12,710-12,680$ \\
\hline
\end{tabular}

${ }^{a}$ Calibration was performed by Beta Analytic using the IntCal98 calibration database (Stuiver et al. 1998).

\section{Soil Analyses}

Stratigraphic sections from the field component of the project were analyzed at Oregon State University (OSU) and at the United States Department of Agriculture's Natural Resources Conservation Service (NRCS) National Soil Survey Laboratory (NSSL) in Lincoln, Nebraska, USA. The OSU lab analyzed particle size, textural classification, $\mathrm{pH}$, and loss on ignition; NRCS provided soil characterization data such as particle size determinations and textural classifications, for classifying the soils within the USDA system based on soil taxonomy. 
Soil samples were submitted for chemical analysis to ALS Chemex Company (USA), which applied inductively coupled plasma spectrometry (ICP). We also submitted soil samples for chemical analysis from 2 other bluffs, Samuel H Boardman State Park and Whiskey Run; 2 recent coastal midden sites, 35-CS-3 in the upper Coquille Estuary near Bullards State Park and 35-CS-43 on Port of Bandon property near the mouth of the Coquille River; a mid-Holocene coastal site near Port Orford; and several near-coastal locations with alluvial deposits lacking in archaeological material. We developed a database from these tests and earlier tests of samples from 35-CS-3 and 35-CS-43 and from 4 non-archaeological control sites near them (Hall and Radosevich 1995). The ALS Chemex ICP analysis uses a 4-acid digestion process to produce a precise measurement of the sample's chemical components in parts per million. Eighteen of the 24 elements analyzed were abundant enough to use in initial descriptions, and of these, 13 possessed sufficient variation to detect patterns among the sites. These are calcium, chromium, cobalt, copper, iron, magnesium, lead, nickel, phosphorus, strontium, titanium, vanadium, and zinc. Whereas some chemicals reflect parent materials and sediment processes, others reflect anthropogenic processes, i.e. inputs from human use of a site. We used the Statistical Package for the Social Sciences (SPSS) and its cluster analysis to group samples that were the most similar chemically.

\section{Lithic Analysis}

Author Willis conducted the lithic tool and debitage analysis. The lithic tools, 23 from the 2 units and 1 from the edge of the bluff, were segregated by type based on macroscopic attributes and were described by material, condition, typology, weight, and provenance. The debitage assemblage of 1239 pieces was subjected to an aggregate analysis, utilizing both size and weight measurements, and typological analyses consisting of a free-standing typology, a technological typology, and a triple cortex typology (Sullivan and Rozen 1985; Andrefsky 1998; Odell 2004).

\section{RESULTS}

\section{${ }^{14} \mathrm{C}$ Tests}

The $5{ }^{14} \mathrm{C}$ tests ranged from $2600 \pm 40 \mathrm{BP}$ at $89-91 \mathrm{~cm}$ to $11,000 \pm 140 \mathrm{BP}$ at $235-245 \mathrm{~cm}$ (Table 1). Dates from the 2 units support each other and suggest that the identified strata apply across the excavated portions of the site. When relationships among the dates are examined stratigraphically, it appears that the lower sediments are more compressed, or that in the upper aeolian strata, sedimentation is greater. For the levels holding cultural materials and charcoal samples, however, the rate of deposition - as estimated by dividing the number of ${ }^{14} \mathrm{C}$ yr between assays by the depth at which the charcoal was retrieved - is remarkably consistent: $67.86 \mathrm{yr} / \mathrm{cm}$ between charcoal samples from level 8, Unit B, and the charcoal at $150 \mathrm{~cm}$ in Unit B, and $63.75 \mathrm{yr} / \mathrm{cm}$ between the charcoal in level 13 and level 21, Unit A.

Relevance of the ${ }^{14} \mathrm{C}$ determinations to prehistory at 35 -CS-9 is determined by their association with cultural materials. The oldest ${ }^{14} \mathrm{C}$ charcoal sample lies about $20 \mathrm{~cm}$ below the deepest artifact. If the $20 \mathrm{~cm}$ of sediment between these levels was deposited at the rate suggested by the above interpolation, the deepest retrieved lithic debitage piece would date approximately $1280 \mathrm{yr}$ after $11,000{ }^{14} \mathrm{C}$ BP, i.e. $9720{ }^{14} \mathrm{C}$ BP. Because it is possible that deposition differed, or that the lithic piece had been displaced downwards, we do not make a specific claim about the antiquity of cultural materials at 35-CS-9, but we suggest that these tantalizing data, and thus the site as a whole, should be considered to date to the early Holocene. Because sediments of late Pleistocene age are clearly present, this site could hold cultural deposits of that era as well. 


\section{Soil Descriptions}

Analysis of the sediments at 35-CS-9 helped us reconstruct the environment of the past and determine what aspects of the prehistoric record could have been preserved. Sediments at 35-CS-9 are eolian sands over alluvial and marine deposits that rest on strongly cemented sandstone at a depth of $350 \mathrm{~cm}$ (Table 2), where the 6 upper strata are separated from the sandstone bedrock by a layer of extremely gravelly sand. As suggested in the discussion of sedimentation rates, it appears that the forces working on the uppermost stratum $(0-73 \mathrm{~cm})$ are quite different from those of the several middle strata $(73-244 \mathrm{~cm})$, which are the primary strata where artifacts providing evidence of past human occupations were recovered in test units.

Table 2 Soil attributes of strata at Bandon Ocean Wayside (35-CS-9), Oregon.

\begin{tabular}{|c|c|c|c|c|c|}
\hline Stratum depth & Color ${ }^{\mathrm{a}}$ & $\begin{array}{l}\text { USDA textural } \\
\text { classification }^{\mathrm{a}}\end{array}$ & $\begin{array}{l}\text { Particle size }{ }^{b} \\
(\%)\end{array}$ & $\mathrm{pH}^{\mathrm{b}}$ & $\begin{array}{l}\text { Loss on } \\
\text { ignition }^{\mathrm{b}} \\
(\%)\end{array}$ \\
\hline $\begin{array}{l}\text { A } \\
0-73 \mathrm{~cm}\end{array}$ & $\begin{array}{l}\text { v.dk.gr.brn. }(2,5 Y \text { 3/2) moist } \\
\text { gr. brn. }(2.5 \mathrm{Y} 5 / 2) \text { dry }\end{array}$ & fine sand & $\begin{array}{c}0.6 \text { clay; } \\
0.5 \text { silt; } \\
98.9 \text { sand }\end{array}$ & 6.5 & 1.59 \\
\hline $\begin{array}{l}2 \mathrm{Ab} 1 \\
73-115 \mathrm{~cm}\end{array}$ & $\begin{array}{l}\text { black (10YR 2/1) moist } \\
\text { v.dk.gr.brn. (10YR 3/2) dry }\end{array}$ & sandy loam & $\begin{array}{l}13.9 \text { clay; } \\
18.7 \text { silt; } \\
67.5 \text { sand }\end{array}$ & 6.4 & 7.45 \\
\hline $\begin{array}{l}2 \mathrm{Ab} 2 \\
115-136 \mathrm{~cm}\end{array}$ & $\begin{array}{l}\text { v.dk.brn. (10YR 2/2) moist } \\
\text { brown (10YR 4/3) dry }\end{array}$ & loam & $\begin{array}{l}21.7 \text { clay; } \\
41.2 \text { silt; } \\
37.1 \text { sand }\end{array}$ & 6.2 & 8.36 \\
\hline $\begin{array}{l}\text { 2Bwb1 } \\
136-167 \mathrm{~cm}\end{array}$ & $\begin{array}{l}\text { dk.brn. (7.5YR 3/4) moist } \\
\text { brown }(7.5 \text { YR 4/4) dry }\end{array}$ & loam & $\begin{array}{l}21.5 \text { clay; } \\
40.2 \text { silt; } \\
38.3 \text { sand }\end{array}$ & 6.4 & 7.87 \\
\hline $\begin{array}{l}3 \mathrm{Bwb} 2 \\
167-244 \mathrm{~cm}\end{array}$ & $\begin{array}{l}\text { brown }(7.5 \mathrm{YR} 4 / 4) \text { moist } \\
\text { brown }(7.5 \mathrm{YR} 5 / 4) \text { dry }\end{array}$ & $\begin{array}{l}\text { sandy clay } \\
\text { loam }\end{array}$ & $\begin{array}{l}20.9 \text { clay; } \\
16.6 \text { silt; } \\
62.5 \text { sand }\end{array}$ & 6.2 & 4.94 \\
\hline $\begin{array}{l}4 \mathrm{Cb} 1 \\
244-287 \mathrm{~cm}\end{array}$ & $\begin{array}{l}\text { yell. brn. (10YR 5/4) moist } \\
\text { lt.yell.brn. (10YR 6/4) dry }\end{array}$ & $\begin{array}{l}\text { loamy } \\
\text { fine sand }\end{array}$ & $\begin{array}{c}3.3 \text { clay; } \\
2.0 \text { silt; } \\
94.7 \text { sand }\end{array}$ & 6.4 & 2.10 \\
\hline $\begin{array}{l}5 \mathrm{Cb} 2 \\
287-350 \mathrm{~cm} \\
6 \mathrm{R} \\
350-360 \mathrm{~cm}\end{array}$ & & $\begin{array}{l}\text { extremely } \\
\text { gravelly sand } \\
\text { very strongly } \\
\text { cemented } \\
\text { sandstone }\end{array}$ & & & \\
\hline
\end{tabular}

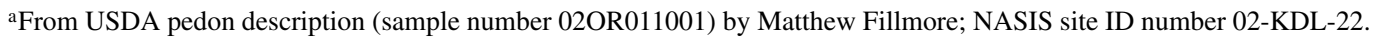
b Analysis by Central Analytical Laboratory, Oregon State University, Department of Crop and Soil Science.

The surface stratum (A horizon) consists predominantly of eolian sands with minimal amounts of silt and clay, and a clear, smooth boundary separates this stratum from the one below it (2Ab1 horizon). In combination with the second stratum's higher silt and clay percentages and decrease in sand content, this smooth boundary clearly indicates a lithologic discontinuity between the overlying eolian sands and the underlying sediments beginning at the top of the 2Ab1 horizon. Lithologic discontinuities such as this one indicate the beginning of a period of landscape instability where erosional and depositional processes dominate and where soil development is minimal. ${ }^{14} \mathrm{C}$ dates from levels of test units slightly below the discontinuity suggest that this period began sometime after 
$2600 \mathrm{BP}$, and the distribution of lithic tools and debitage suggests that the major occupation of the site was in the older period in which alluvial deposits predominate and soil development occurred.

Pedogenic processes of soil formation appear evident in horizons 2Ab1, 2Ab2, 2Bwb1, 3Bwb2, from depths of 73-244 cm (Table 2). Soil colors transition from darker above to lighter below, indicating a decrease in organic matter with depth; the grade and size of the structure along with soil consistency (the degree and kind of cohesion that soils exhibit) increase with depth as does the texture of each subsequent horizon-all indicators of soil development and thus of landscape stability. Clay content increases significantly in most of this zone, while silt and sand contents fluctuate; when silts decrease, sands increase.

An abrupt wavy boundary is evident at $167 \mathrm{~cm}$ (3Bwb2 horizon). There, a significant decrease in silt content coupled with an almost doubled sand content indicates a depositional event resulting in a second lithologic discontinuity within the soil. Texture changes to sandy clay loam, grade and size of structure becomes more developed, and soil consistency increases. A third lithologic discontinuity occurs at $244 \mathrm{~cm}$, indicating a depositional event high in sand content with only minimal amounts of silts and clays and very similar to the surface horizon in composition of the fine earth fraction (sand, silt, and clay) and soil characteristics such as texture, structure, and consistency. A fourth lithologic discontinuity occurs at $287 \mathrm{~cm}$ where a stratum of extremely gravelly sand indicates an earlier deposition event. Finally, this layer of extremely gravelly sand overlies the last lithologic discontinuity with very strongly cemented sandstone bedrock at a depth of $350 \mathrm{~cm}$.

Although 35-CS-9 and 35-CU-67C are similar in that both are bluff sites and consist of eolian deposits overlying sediments ultimately of marine origin, they differ considerably in soil properties and thus in landscape history. At 35-CU-67C, the stratum with the largest quantity of clay and silt is the first, $0-20 \mathrm{~cm}$, which has $8.3 \%$ and $23.6 \%$ of clay and silt, respectively. The second and only other known culture-bearing stratum (20-84 cm depth) has $1.7 \%$ and $12.4 \%$ clay and silt, respectively, more sand than all but the first and fifth strata at 35-CS-9. In the six 35-CS-9 samples, $\mathrm{pH}$ varied little, only from 6.2-6.5, whereas $\mathrm{pH}$ values in the 2 culture-bearing samples at $35-\mathrm{CU}-67 \mathrm{C}$ were 6.3 and 5.8. LOI samples at 35-CS-9 ranged from $1.59-8.36 \%$, while the 2 culture-bearing strata at $35-\mathrm{U}-67 \mathrm{C}$ were $6.68 \%$ and $4.24 \%$.

\section{Soil Chemistry}

Using cluster analysis in SPSS, we categorized soil samples into groups that minimize the variation among the members of each group but maximize the (theoretical) distance between groups. The goal was simply to learn which samples are most similar and what chemical variables determine the patterns of similarity. After repeating the analysis by specifying that SPSS create 2, 3, 4, 5, and 6 groups, it appeared that the 4-way solution was a reasonable fit for the data. The analysis identified the variables phosphorus, calcium, and strontium as indicators of dense midden deposits, in 2 levels (higher and lower), which are shown as clusters 1 and 2 in Table 3 . Another clearly identified group (cluster 4 in Table 3) was high in chromium, cobalt, vanadium, and iron, but quite low in calcium and zinc, and intermediate in other chemical values. Samples in the remaining cluster (3) were not high or low in any chemical.

Pertinent to this report, cluster 4 consisted of 3 of the 8 samples tested from 35-CS-9 at 30, 59, and $75 \mathrm{~cm}$ and all four $35-\mathrm{CU}-67 \mathrm{C}$ samples at $6,30,60$, and $84 \mathrm{~cm}$. Two of the high-chromium samples from 35-CS-9 lie in the aeolian deposits and above the discontinuity, while the third, at $75 \mathrm{~cm}$, taken a few meters from the place where the 73-cm border was measured, is approximately at the boundary between the first and second strata. The 5 other samples from 35-CS-9, ranging from 130-235 cm, 
Table 3 Mean chemical values ${ }^{\mathrm{a}}$ in 4 clusters of coastal soil samples.

\begin{tabular}{lrrrr}
\hline Chemical, ppm & \multicolumn{1}{c}{ Cluster 1 } & \multicolumn{1}{c}{ Cluster 2 } & Cluster 3 & \multicolumn{1}{c}{ Cluster 4 } \\
\hline Calcium & 7.9988 & 4.7183 & 1.1809 & 1.9686 \\
Chromium & 487.6250 & 473.3333 & 601.3962 & 4665.7143 \\
Cobalt & 6.1250 & 7.1667 & 7.5472 & 18.7143 \\
Copper & 24.5000 & 22.0000 & 17.9623 & 15.1429 \\
Iron & 1.4175 & 1.6692 & 2.2991 & 4.0800 \\
Lead & 23.5000 & 14.0833 & 21.0566 & 6.8571 \\
Magnesium & 0.4638 & 0.5633 & 0.6109 & 1.0643 \\
Nickel & 26.6250 & 34.5833 & 44.9245 & 63.4286 \\
Phosphorus & 8640.0000 & 4136.6667 & 614.1509 & 291.4286 \\
Strontium & 553.7500 & 403.5000 & 177.2830 & 176.8571 \\
Titanium & 0.1750 & 0.2042 & 0.2892 & 0.4314 \\
Vanadium & 40.5000 & 50.2500 & 77.1509 & 154.8571 \\
Zinc & 105.2500 & 68.8333 & 48.4151 & 71.2857 \\
\hline
\end{tabular}

aThese 13 chemical elements varied substantially among clusters. Note that many, but not all, show a gradient from the most dense midden samples in cluster 1 to the 2 bluff sites (35-CU-67C and 35CS-9) in cluster 4. Chemicals such as chromium go from a high point in cluster 4 to a low value in cluster 1, whereas others such as phosphorus vary in the opposite direction.

decreased in chromium values with depth and are classified with the cluster 3 samples. None of the samples from these 2 bluff sites had even moderately high values of phosphorus, calcium, and strontium, which indicate a dense midden environment. However, as Table 3 shows, samples in clusters 1 and 2, which we categorized as "midden samples," have extremely high levels of phosphorus. Several comparison samples from late prehistoric middens did not have high enough anthropogenic content to classify with the high midden samples either but were grouped in cluster 3 along with some from 35-CS-9, the non-cultural Whiskey Run bluff, and several non-cultural alluvial sites. Thus, this analysis does not exclude the possibility of 35-CS-9 holding decomposed midden material.

\section{Lithic Patterns at 35-CS-9}

The lithic tool assemblage from both test units, including formed lithic tools in levels 4 through 15 (Table 4) and debitage from levels 2 through 19 (Table 5), provides a glimpse of toolkit design in the middle Holocene on the southern Oregon coast. The multidirectional core technology evident in the tools has both bifacial and amorphous characteristics; most of the latter are cobble cores in early stages of reduction. Late-stage cores can be described as multidirectional with 1 specimen exhibiting bifacial core characteristics. Non-formal modified flake tools, bifacial preforms, projectile points, and cores predominate throughout the series. The debitage assemblage through time reveals a focus on late-stage tool reduction and/or maintenance, as indicated by the predominance of broken flake and flake fragment categories (Sullivan and Rozen 1985). The presence of cores in early stages of reduction in an assemblage with little evidence for early-stage debitage could be due to the small sample size or could have occurred if the tool makers immediately modified the flakes they produced. Only further excavation and recovery of more tools can determine which possibility is correct.

The lithic debitage consists of 89\% cryptocrystalline silicate (CCS) material in test unit A and $93 \%$ $\mathrm{CCS}$ in test unit B; the remaining debitage consists of roughly equal quantities of basalt, metamorphic, and quartzite materials. Local sources of CCS exist near the site, as they do all along the Ore- 
Table 4 Stone tools at Bandon Ocean Wayside (35-CS-9), Oregon.

\begin{tabular}{|c|c|c|c|c|c|c|}
\hline Provenance & $\begin{array}{l}\mathrm{Lab} \\
\mathrm{nr}\end{array}$ & Condition & $\begin{array}{l}\text { Depth } \\
(\mathrm{cm})\end{array}$ & Material & Tool category & $\begin{array}{l}\text { Weight } \\
(\mathrm{g})\end{array}$ \\
\hline $\begin{array}{l}\text { Unit A, } \\
\text { level } 4\end{array}$ & 5 & Fragment & $60-75$ & CCS, gray-brown & Bifacial & 0.1 \\
\hline $\begin{array}{l}\text { Unit B, } \\
\text { level } 6\end{array}$ & $\begin{array}{l}75 \\
76\end{array}$ & $\begin{array}{l}\text { Broken } \\
\text { Broken }\end{array}$ & $\begin{array}{l}83-93 \\
83-93\end{array}$ & $\begin{array}{l}\text { CCS, yellow-brown } \\
\text { CCS, red-brown }\end{array}$ & $\begin{array}{l}\text { Modified flake } \\
\text { Finished biface }\end{array}$ & $\begin{array}{l}0.3 \\
2.5\end{array}$ \\
\hline $\begin{array}{l}\text { Unit A, } \\
\text { level } 7\end{array}$ & 13 & Complete & 95-105 & CCS, gray-green & Cobble core & 110.6 \\
\hline $\begin{array}{l}\text { Unit B, } \\
\text { level } 7\end{array}$ & $\begin{array}{r}84 \\
92 \\
131\end{array}$ & $\begin{array}{l}\text { Complete } \\
\text { Broken } \\
\text { Broken }\end{array}$ & $\begin{array}{l}93-103 \\
93-103 \\
93-103\end{array}$ & $\begin{array}{l}\text { CCS, gray-brown } \\
\text { CCS, yellow-brown } \\
\text { CCS, yellow-brown }\end{array}$ & $\begin{array}{l}\text { Core } \\
\text { Cobble core } \\
\text { Modified flake }\end{array}$ & $\begin{array}{r}98.4 \\
23.1 \\
1.6\end{array}$ \\
\hline $\begin{array}{l}\text { Unit A, } \\
\text { level } 8\end{array}$ & $\begin{array}{l}16 \\
18 \\
19\end{array}$ & $\begin{array}{l}\text { Complete } \\
\text { Complete } \\
\text { Complete }\end{array}$ & $\begin{array}{l}105-115 \\
105-115 \\
105-115\end{array}$ & $\begin{array}{l}\text { Quartzite } \\
\text { CCS, red-brown } \\
\text { CCS, red-brown }\end{array}$ & $\begin{array}{l}\text { Modified flake } \\
\text { Cobble core } \\
\text { Modified flake }\end{array}$ & $\begin{array}{r}19.5 \\
14.1 \\
2.3\end{array}$ \\
\hline $\begin{array}{l}\text { Unit B, } \\
\text { level } 8\end{array}$ & $\begin{array}{r}96 \\
101\end{array}$ & $\begin{array}{l}\text { Fragment } \\
\text { Broken }\end{array}$ & $\begin{array}{l}103-113 \\
103-113\end{array}$ & $\begin{array}{l}\text { CCS, dark gray } \\
\text { CCS, brown-gray }\end{array}$ & $\begin{array}{l}\text { Biface/preform } \\
\text { Modified flake }\end{array}$ & $\begin{array}{l}2.6 \\
0.4\end{array}$ \\
\hline $\begin{array}{l}\text { Unit A, } \\
\text { level } 9\end{array}$ & $\begin{array}{l}25 \\
26 \\
29\end{array}$ & $\begin{array}{l}\text { Fragment } \\
\text { Fragment } \\
\text { Complete }\end{array}$ & $\begin{array}{l}115-125 \\
115-125 \\
115-125\end{array}$ & $\begin{array}{l}\text { CCS, red-brown } \\
\text { CCS, dark gray } \\
\text { CCS, yellow-brown/ } \\
\text { red streaks }\end{array}$ & $\begin{array}{l}\text { Exhausted core } \\
\text { Finished biface } \\
\text { Modified flake }\end{array}$ & $\begin{array}{l}9.8 \\
6.4 \\
6.0\end{array}$ \\
\hline $\begin{array}{l}\text { Unit B, } \\
\text { level } 9\end{array}$ & $\begin{array}{l}105 \\
106\end{array}$ & $\begin{array}{l}\text { Broken } \\
\text { Complete }\end{array}$ & $\begin{array}{l}113-123 \\
113-123\end{array}$ & $\begin{array}{l}\text { CCS, gray-green } \\
\text { CCS, gray-brown }\end{array}$ & $\begin{array}{l}\text { Core, bifacial } \\
\text { Core, multi- } \\
\text { directional }\end{array}$ & $\begin{array}{l}40.6 \\
41.6\end{array}$ \\
\hline $\begin{array}{l}\text { Unit A, } \\
\text { level } 10\end{array}$ & $\begin{array}{l}30 \\
31 \\
36 \\
37\end{array}$ & $\begin{array}{l}\text { Broken } \\
\text { Unbroken cobble } \\
\text { Broken } \\
\text { Broken }\end{array}$ & $\begin{array}{l}125-135 \\
125-135 \\
125-135 \\
125-135\end{array}$ & $\begin{array}{l}\text { CCS, gray-green } \\
\text { Poss. quartzite, gray-brown } \\
\text { CCS, dark red } \\
\text { CCS, brown-red }\end{array}$ & $\begin{array}{l}\text { Cobble } \\
\text { Manuport } \\
\text { Modified flake } \\
\text { Modified flake }\end{array}$ & $\begin{array}{r}93.8 \\
640.9 \\
1.5 \\
0.3\end{array}$ \\
\hline $\begin{array}{l}\text { Unit A, } \\
\text { level } 15\end{array}$ & 49 & Fragment & $175-185$ & CCS, gray yellow-brown & Biface/preform & 26.1 \\
\hline $\begin{array}{l}\text { Unit B, } \\
\text { level } 15\end{array}$ & 125 & Complete & $173-183$ & CCS, gray-brown & Cobble core & 95.6 \\
\hline Bluff edge & 60 & Very worn & 150 & CCS, dark gray & Core hammer & 299.8 \\
\hline
\end{tabular}

gon coast. The source of the single piece of obsidian debitage, recovered in level 9 of unit A, was determined to be the Spodue Mountain chemical group in central Oregon (C Skinner, Northwest Research Obsidian Studies Laboratory, personal communication, 2003).

Throughout, the tool assemblage appears to be a generalized and transportable toolkit that would be ideal for foragers using marine and terrestrial resources; the flake and core/bifacial strategy would have allowed for optimal mobility. The presence of multiple types of cores alludes to the importance of manufacturing flake tools, and the lithic toolkit used at 35-CS-9 during the Holocene could have been used to construct a larger, and possibly more specialized, organic toolkit. The modified flake tools can also be viewed as support for the evidence of possible hide or plant processing. Because no groundstone artifacts were found in the 2 test units, it is possible that plant processing was either not performed at 35-CS-9 or not performed regularly; however, more excavations are required to determine patterning of artifacts and site functions. Mammal processing is quite probable, considering that all of the modified flake tools, from all depths, retain steep edge angles that would be conducive to animal hide working and processing. Even though there are 1239 pieces of debitage, along with 24 lithic tools, the sample size at 35-CS-9 is relatively small and the artifacts were taken from a restricted part of the site; thus, caution should be taken when interpreting the site's function as based on the lithic finds. 
Table 5 Debitage categorized in Sullivan and Rozen (1985) system, at 35-CS-9 (Bandon Ocean Wayside), Oregon.

\begin{tabular}{cccclc}
\hline Level & $\begin{array}{l}\text { Debris total } \\
(\mathrm{A}, \mathrm{B})\end{array}$ & $\begin{array}{l}\text { Flake fragments } \\
\text { total }(\mathrm{A}, \mathrm{B})\end{array}$ & $\begin{array}{l}\text { Broken flakes } \\
\text { total }(\mathrm{A}, \mathrm{B})\end{array}$ & $\begin{array}{l}\text { Complete flakes } \\
\text { total }(\mathrm{A}, \mathrm{B})\end{array}$ & $\begin{array}{l}\text { All categories } \\
\text { total }(\mathrm{A}, \mathrm{B})\end{array}$ \\
\hline 2 & $0(0,0)$ & $25(3,22)$ & $6(1,5)$ & $1(1,0)$ & $32(5,27)$ \\
3 & $0(0,0)$ & $15(8,7)$ & $4(1,3)$ & $0(0,0)$ & $19(9,10)$ \\
4 & $0(0,0)$ & $16(14,2)$ & $5(5,0)$ & $2(2,0)$ & $23(21,2)$ \\
5 & $1(0,1)$ & $33(2,31)$ & $6(1,5)$ & $1(1,0)$ & $41(4,37)$ \\
6 & $12(1,11)$ & $175(6,169)$ & $45(0,45)$ & $3(0,3)$ & $235(7,228)$ \\
7 & $11(1,10)$ & $208(30,178)$ & $48(10,38)$ & $5(4,1)$ & $272(45,227)$ \\
8 & $9(3,6)$ & $166(44,122)$ & $54(12,42)$ & $4(2,2)$ & $233(61,172)$ \\
9 & $8(5,3)$ & $130(86,44)$ & $33(17,16)$ & $1(1,0)$ & $172(109,63)$ \\
10 & $3(3,0)$ & $38(25,13)$ & $18(10,8)$ & $0(0,0)$ & $59(38,21)$ \\
11 & $1(1,0)$ & $40(28,12)$ & $9(7,2)$ & $0(0,0)$ & $50(36,14)$ \\
12 & $3(2,1)$ & $23(12,11)$ & $3(1,2)$ & $0(0,0)$ & $29(15,14)$ \\
13 & $6(1,5)$ & $14(7,7)$ & $8(7,1)$ & $0(0,0)$ & $28(15,13)$ \\
14 & $0(0,0)$ & $17(16,1)$ & $6(4,2)$ & $1(1,0)$ & $24(21,3)$ \\
15 & $1(0,1)$ & $5(1,4)$ & $0(0,0)$ & $0(0,0)$ & $6(1,5)$ \\
16 & $0(0,0)$ & $5(4,1)$ & $2(2,0)$ & $0(0,0)$ & $7(6,1)$ \\
17 & $0(0,0)$ & $2(2,0)$ & $1(0,1)$ & $0(0,0)$ & $3(2,1)$ \\
18 & $0(0,0)$ & $4(4,0)$ & $1(1,0)$ & $0(0,0)$ & $5(5,0)$ \\
19 & $0(0,0)$ & $0(0,0)$ & $1(1,0)$ & $0(0,0)$ & $1(1,0)$ \\
\hline
\end{tabular}

\section{DISCUSSION}

Site 35-CS-9 within the Bandon Ocean Wayside is important because it is one of very few excavated sites representing the middle Holocene on the Oregon coast. It also contributes to the search for the earliest coastal sites on the Oregon coast because it provides evidence of an early-Holocene occupation, and it has late-Pleistocene sediments and potentially could hold cultural deposits of that antiquity. In addition, its geomorphical and technological features suggest attributes that may characterize other late-Pleistocene, early-Holocene, and middle-Holocene sites on the Pacific coast. From a cultural management perspective, this site is important because it shows that non-midden sites of great antiquity do exist; resource managers as well as archaeologists need to know this in order to protect them.

This site differs from 35-CU-67C in that there were no artifacts and only 1 piece of debitage made of obsidian. In this, it has much in common with many other coastal sites, particularly of Oregon's middle coast. By contrast, obsidian was prominent at 35-CU-67C, both in tools and debitage, which were chemically traced to quarries at Medicine Lake, California, and Spodue Mountain, south-central Oregon (C Skinner, personal communication, 2003). The closer proximity of 35-CU-67C to these much-used obsidian deposits could explain the difference, or perhaps the abundant resources of CCS near 35-CS-9 is a sufficient explanation. Although evidence of late-stage reduction and tool maintenance is present, the intensity of occupation through the Holocene cannot be inferred. In any case, more excavations are required at 35-CS-9 to better understand what materials its residents used and what their settlement entailed.

The soil chemistry analysis found a similarity between the 2 old bluff sites in the upper layers of deposition, particularly in their chemical concentrations; furthermore, both sites lack any chemical indicators of anthropogenic midden deposits. The soil chemistry profiles, as well as the type of arti- 
facts found, do not suggest a long-term village settlement but rather an opportunistic sporadicallyused camp with a creek providing fresh water and a rock quarry providing access to tool-making materials. It is likely that, in addition to fresh water, it was the CCS deposits that made this site attractive to people of the middle Holocene. In some ways, the Bandon Ocean Wayside site seems more complex than Indian Sands. Perhaps this impression is because the lesser deflation at Bandon Ocean Wayside allowed for the preservation of an occupation that covers much of the Holocene.

The integrity of its Holocene deposits at Bandon Ocean Wayside alone-a very unusual feature in any Oregon coastal site-suggests that the site should be studied on a much larger scale with a block excavation in which artifacts are mapped in situ. Tools and debitage demonstrate that 35-CS-9 was used over a period of millennia, but the extent and character of the occupation must be determined by additional excavations. The full record of the site is not clear from our preliminary excavations because we excavated only 2 test units; as Lyman (1991) showed, site interpretation depends heavily on how extensively a site is sampled.

Clearly, the identification of early late-Pleistocene and early-Holocene coastal sites provides a significant challenge. There is no formula for identifying coastal areas and sediments that contain evidence of sites of the Pleistocene-Holocene transition on the Oregon coast, but this description of work at 35-CS-9 shows that they do exist and that the key to finding them is to use a geoarchaeological approach that includes mapping of strata and analysis of sediments. Excavation and recovery of cultural materials along with datable charcoal or other organic remnants are essential to establishing a chronology to unravel the Holocene and potentially the pre-Holocene cultural history of the Oregon coast.

\section{ACKNOWLEDGMENTS}

This research was funded by the NOAA Office of Sea Grant and Extramural Programs, U.S. Department of Commerce under grant number NA76RG0476 and project number R/CC-04, and by appropriations made by the Oregon State legislature. The U.S. government is authorized to produce and distribute reprints for governmental purposes notwithstanding copyright notations above. Craig Skinner of Northwest Research Obsidian Studies laboratory generously provided trace element characterization of obsidian debitage. We greatly appreciate the encouragement and support of the Cultural Resource Program of the Coquille Indian Tribe and the work of many student field assistants.

\section{REFERENCES}

Andrefsky W Jr. 1998. Lithics: Macroscopic Approaches to Analysis. Cambridge: Cambridge University Press. $258 \mathrm{p}$.

Davis LG, Punke ML, Hall RL, Fillmore M, Willis SC. 2004. Evidence for a late Pleistocene occupation on the southern northwest coast. Journal of Field Archaeology 29:1-10.

Dixon EJ. 2001. Human colonization of the Americas: timing, technology and process. Quaternary Science Reviews 20:277-99.

Erlandson JM. 2002. Anatomically modern humans, maritime voyaging, and the Pleistocene colonization of the Americas. In: Jablonski NG, editor. The First Americans. San Francisco: California Academy of Sciences. Memoirs 27. p 59-92.

Erlandson JM, Moss M. 1993. Report to Oregon State Parks, June 27, 1993, on the condition of 35-CS-9 [on file at the Oregon State Historic Preservation Office Salem, Oregon].

Erlandson JM, Kennett DJ, Ingram BL, Guthrie DA, Morris DP, Tveskov MA, West GJ, Walker PL. 1996. An archaeological and paleontological chronology for Daisy Cave (CA-SMI-261), San Miguel Island, California. Radiocarbon 38(2):355-73.

Fedje DW, Christensen T. 1999. Modeling paleoshorelines and locating early Holocene coastal sites in Haida Gwaii. American Antiquity 64(4):635-52.

Fedje DW, Wigen RJ, Mackie Q, Lake CR, Sumpter ID. 2001. Preliminary results from investigations at Kilgii Gwaay: an early Holocene archaeological site on Ellen Island, Haida Gwaii, British Columbia. Canadian Journal of Archaeology 25:98-120.

Fedje DW, Mackie Q, Dixon EJ, Heaton TH. 2004. Late Wisconsin environments and archaeological visibility 
on the northern Northwest coast. In: Madsen DB, editor. Entering America. Northeast Asia and Beringia Before the Last Glacial Maximum. Salt Lake City: University of Utah Press. p 93-138.

Hall RL, editor. 1995. People of the Coquille Estuary. Corvallis: Words and Pictures Unlimited. $224 \mathrm{p}$.

Hall RL. 2000. Locating possible late Pleistocene and early Holocene archaeological sites on the southern Oregon coast. URL: http://oregonstate.edu/dept/anthropology/SeaGrantWeb/origprop.htmll.

Hall RL, Radosevich S. 1995. Geoarchaeological analysis of a site in the Cascadia Subduction Zone on the southern Oregon coast. Northwest Anthropological Research Notes 29:123-40.

Hall RL, McCarthy D, Hall DA. 2002. How were North American sites of the Pleistocene-Holocene transition discovered? North American Archaeologist 23(2): 145-56.

Hall RL, Roy D, Boling D. 2004. Pleistocene migration routes into the Americas: human biological adaptations and environmental constraints. Evolutionary Anthropology 13(4):132-44.

Lyman RL. 1991. Prehistory of the Oregon Coast. San Diego: Academic Press. 391 p.

Lyman RL, Ross RE. 1988. Oregon coast prehistory: a critical history and a model. Northwest Anthropological Research Notes 22:67-119.

Madsen DB, editor. 2004. Entering America. Northeast Asia and Beringia Before the Last Glacial Maximum, Salt Lake City: University of Utah Press. 486 p.

Mandryk CAS, Josenhans H, Fedje DW, Mathewes RW. 2001. Late Quaternary paleoenvironments of northwestern North America: implications for inland versus coastal migration routes. Quaternary Science Review 20:301-14.
Minor R. 1986. An evaluation of archaeological sites on state park lands along the Oregon coast. Eugene, Oregon: Heritage Research Associations. Report nr 44. $148 \mathrm{p}$.

Minor R. 1994. Blacklock Point Lithic Site. Registration form for National Register of Historic Places, National Park Service, Washington D.C.

Minor R, Toepel KA. 1986. The archaeology of the Tahkenitch landing site: early prehistoric occupation on the Oregon coast [report to the Siuslaw National Forest]. Eugene, Oregon: Heritage Research Associations. Report No. 46. 117 p.

Odell GH. 2004. Lithic Analysis. Manuals in Archaeological Method, Theory, and Technique. New York: Kluwer Academic/Plenum Publishing. 262 p.

Ramsey CP, Griffiths P, Fedje DW, Wigen RJ, Mackie Q. 2004. Preliminary investigation of a late Wisconsinan fauna from K1 Cave, Queen Charlotte Islands (Haida Gwaii), Canada. Quaternary Research 62(1):105-9.

Ross RE. 1975. Report to Oregon State Parks on the condition of 35-CS-9, September 3, 1975 [on file at the Oregon State Historic Preservation Office, Salem, Oregon].

Ross RE. 1984. Terrestrial oriented sites in a marine environment along the southern Oregon coast. Northwest Anthropological Research Notes 18(2): 241-55.

Stuiver M, Reimer PJ, Bard E, Beck JW, Burr GS, Hughen GS, Kromer B, McCormac G, van der Plicht J, Spurk M. 1993. IntCa198 radiocarbon age calibration, 24,000-0 cal BP. Radiocarbon 40(3):1041-83.

Sullivan AP III, Rozen KC. 1985. Debitage analysis and archaeological interpretation. American Antiquity 50: 755-79. 